\title{
EFISIENSI PENGGUNAAN ENERGI MATAHARI PADI GOGO (Oryza SativaL.) LOKAL ACEH DENGAN KARAKTER DAUN BERBEDA
}

\author{
Syukri $^{\left.{ }^{*}\right)}$, Abdurrachman ${ }^{2}$ dan Risky Ridha ${ }^{1}$ \\ ${ }^{1)}$ Dosen Program Studi Agroteknologi, Fakultas Pertanian, Universitas Samudra \\ ${ }^{2)}$ Dosen Program Studi Agribisnis, Fakultas Pertanian, Universitas Samudra \\ *e-mail: syukri.risyad@unsam.ac.id
}

\begin{abstract}
ABSTRAK
Efisiensi konversi energi sangat tergantung pada faktor lingkungan dan kemampuan tanaman untuk menerima intensitas radiasi matahari. Pemilihan varietas berkaitan erat dengan bentuk kanopi dan laju pertumbuhan tanaman menentukan kemampuan tanaman untuk menangkap dan menyerap intensitas radiasi matahari.Pengaruh tipe tanaman terhadap hasil sangat tergantung pada struktur kanopi.Informasi mengenai karakter daun padi gogo lokal Aceh terhadap efesiensi penggunaan energi matahari belum banyak tersedia. Penelitian ini bertujuan untuk mengkaji pengaruh dari karakter daun padi gogo lokal Aceh terhadap efisiensi penggunaan energi matahari sehingga diperoleh karakter morfologi daun yang ideal untuk menjadi tanaman yang memiliki ideotipe berdaya hasil tinggi. Bahan tanam yang digunakan terdiri atas aksesi padi gogo lokal Aceh yaitu Sebeso, Sigedul, Bengkok, Rias Kuning, Rias Putih, Simerah, Bontok, Ramos Gunung dan Gembel. Penelitian ini menggunakan metode deskriptif yaitu dengan pengamatan secara in situ pada lokasi penanaman padi di lahan petani dengan dipilih 10 rumpun sebagai sampel pada setiappadi gogo lokal di masing-masing lokasi (Komnas Plasma Nutfah, 2003; IRRI, 2013). Hasil analisis deskriptif kultivar Bengkok memiliki karakter daun bendera yang lebih panjang sebesar $41,15 \mathrm{~cm}$. Karakter daun kedua dan ketiga terpanjang diperoleh pada kultivar Bontok sebesar masing-masing 72,90 dan 83,20 cm, sedangkan karakter daun bendera, kedua dan ketiga terlebar diperoleh pada kultivar Rias Kuning sebesar masing-masing 2,43, 2,33 dan 2,28 cm. Sudut daun kultivar padi gogo lokal kecuali Bengkok berkisar antara 5,0-27,5 , sehingga memiliki karakter kanopi daun yang tegak (kriteria tegak $<45^{\circ}$ ), kultivar Bontok, Rias Kuning dan Sebeso memiliki sudut daun yang lebih kecil $\left(5,0-17,5^{\circ}\right)$. Kultivar Bontok, Rias Kuning dan Sebeso memiliki efisiensi intersepsi (Ei) dan absorbsi (Ea) yang lebih tinggi, pada nilai efisiensi penggunaan energi tertangkap (Epi) terjadi peningkatan seiring dengan bertambahnya umur tanaman. Hal ini sesuai dengan karakter kanopi daun yang tegak dengan sudut daun yang lebih kecil $\left(5,0-17,5^{\circ}\right)$ serta tergolong memiliki luas daun bendera dan kedua lebih besar berkisar antara $64,00-123,02 \mathrm{~cm}^{2}$ sehingga lebih efisien dalam memanfaatkan radiasi matahari yang dapat meningkatkan fotosintesi dan hasil tanaman
\end{abstract}

Kata kunci : Kultivar, Karakter daun, Efisiensi energi matahari.

\section{PENDAHULUAN}

Pertumbuhan tanaman dipengaruhi olehfaktor lingkungan seperti energi radiasi matahari. Energi radiasi matahari berperan dalam proses fotosintesis tanaman untuk menghasilkanasimilat yang digunakan dalam pembentukan bagian-bagian tanaman. Oleh karena itu,produksi biomassa merupakan akumulasi dariradiasi matahari selama priode waktu tertentu. Bobot kering tanaman tergantung pada jumlahradiasi yang diintersepsi selamapertumbuhannya. Dalam pertanaman tingkatintersepsi cahaya ditentukan oleh sebaran daundalam tajuk. Menurut Sitompul, (2016) radiasi matahari yang diintersepsi dalam tajuk tanamandapat ditaksir dari selisih antara radiasi yangsampai pada permukaan atas tajuk tanamandengan radiasi yang berpenetrasi hingga dibawah tajuk atau permukaan tanah.

Efisiensi konversi energi sangat tergantung pada faktor lingkungan dan kemampuan tanaman untuk menerima intensitas radiasi matahari (Slattery and Ort, 2015). Faktor iklim yang mempengaruhi efisiensi konversi energi surya seperti garis lintang, musim, awan dan konsentrasi $\mathrm{CO}_{2}$ di lingkungan tanaman, sedangkan faktor tanaman adalah posisi dan susunan daun serta jenis pigmen daun (Zhu et al., 2008; Monteith and Unsworth, 2013). Karakter kanopi tanaman yang meliputi posisi dan susunan daun menjadi salah satu faktor yang menentukan tipe tanaman ideal dengan hasil yang lebih tinggi (Yoshida, 1981). Karakter 3 daun bagian atas yang panjang, 
tegak, menyempit dan tebal dijadikan sebagai dasar perakitan varietas padi dengan hasiltinggi (Peng et al., 2008).

Pengaturan kanopi tanaman dapat menangkap lebih banyak energi cahaya, efisiensi dalam penggunaan cahaya, fotosintesis yang lebih besar dan mampu memproduksi biomasa lebih besar (Peng et al., 2008). Menurut Ganghuaet al., (2009) posisi daun yang sesuai dengan sudut daun kecil menyebabkan indeks luas daun yang lebih besar dengan luas lebih rendah per batang. Hal tersebut dapat menyebabkan jumlah malai per $\mathrm{m}^{2}$ lebih banyak.

Daun tegak memungkinkan penetrasi dan distribusi cahaya lebih besar sampai ke bagian bawah dan merata, sehingga meningkatkan fotosintesis tanaman. Fotosintesis tanaman pada kanopi daun tegak sekitar 20\% lebih tinggi dibanding kanopi daun terkulai pada kondisi ILD tinggi (Yoshida, 1981; Murchie et al., 2002). Menurut Abdullah et al.,(2008) perakitan padi tipe baru harus mempunyai daun yang tegak pada bagian atas, horizontal pada bagian bawah, tebal, sempit hingga sedang, berbentuk V, dan berwarna hijau tua. Karakter ini diperlukan untuk meningkatkan produksi biomasa.

Varietas unggul lokal terutama yang tergolong dalam padi jenis indica memiliki daun yang panjang dan horizontal, sehingga bentuk kanopi terkulai. Daun terkulai akan mengurangi penetrasi cahaya, meningkatkankelembaban di bawah kanopi daun, dan mengurangi pergerakan udara. Hal ini akan menurunkan efisiensi fotosintesis (Yoshida, 1981). Yoshida (1981) juga menyatakan fotosintesis pada daun terkulai lebih rendah dibandingkan kanopi daun tegak pada saat intensitas cahaya tinggi.

Informasi mengenai karakter daun padi gogo (Oryza sativa L.) lokal Aceh terhadap efesiensi penggunaan energi matahari belum banyak tersedia. Penelitian ini bertujuan untuk mengkaji pengaruh dari karakter daun padi gogo lokal Aceh terhadap efisiensi penggunaan energi matahari sehingga diperoleh karakter morfologi daun yang ideal untuk menjadi tanaman yang memiliki ideotipe berdaya hasil tinggi.

\section{Tempat dan Waktu Penelitian}

\section{METODELOGI PENELITIAN}

Penelitian ini dilaksanakan di Kecamatan Serbajadi dan Birem Bayeun, Kabupaten Aceh Timur. Waktu pelaksanaan penelitian pada bulan Juni sampai dengan bulan Nopember 2020.

\section{Metode Penelitian}

Pengamatan tanaman padi gogo lokal dilakukansecarain situ, sumber benih berasal dari lokasi eksplorasi. Bahan tanam yang digunakan terdiri atas aksesi padi gogo lokal Aceh yaitu Sebeso, Sigedul, Bengkok, Rias Kuning, Rias Putih, Simerah, Bontok, Ramos Gunung dan Gembel. Penelitian ini menggunakan metode deskriptif yaitu dngan pengamatan secara in situ pada lokasi penanaman padi di lahan petani dengan dipilih 10 rumpun sebagai sampel pada setiappadi gogo lokal di masing-masing lokasi (Komnas Plasma Nutfah, 2003; IRRI, 2013).

\section{Pelaksanaan Penelitian}

Pelaksanaan penelitian diawali dengan pemilihan benih bernas untuk masing-masing varietas dengan cara perendaman dalam air garam, benih yang digunakan adalah benih yang tenggelam secara fisik. Benih tersebut kemudian dikecambahkan terlebih dahulu didalam handuk lembab selama 1 x 24 jam atau sampai benih mengeluarkan koleptil sepanjang $1 \mathrm{~mm}$. Pengambilan data dilakukan pada lahan petani dari masing-masing lokasi dengan luasan plot berukuran $2 \mathrm{~m} \times 2 \mathrm{~m}\left(4 \mathrm{~m}^{2}\right)$. Setiap lubang tanam ditanami sebanyak 2 kecambah, dengan jarak tanam $25 \mathrm{~cm} \times 20 \mathrm{~cm}$. Pemberian pupuk dilakukan sesuai dengan dosis petani. Pemanenan dilakukan secara bertahap disesuaikan dengan umur panen setiap varietas (genotipe) dari masingmasing lokasi danbenih yang diperoleh pada penelitian ini akan disimpan untuk keperluan karakterisasi lainnya.

Pengamatan intensitas cahaya matahari dilakukan di atas dan di bawah tajuk, dari data pengamatan dihitung Ei (efisiensi intersepsi), Ea (efisiensi absorbsi) dan Epi (efisiensi penggunaan energi tertangkap) (Sugito, 2009).Pengukuran intensitas cahaya matahari dilakukan dua minggu sekali pada pagi hari (08.00 WIB), siang hari (12.00 WIB), dan sore hari (17.00 WIB)umur 10 dan 12 MST.

Pengamatan karakter morfologi dilakukan berdasarkan buku panduan Sistem Karakterisasi dan Evaluasi Tanaman Padi (Komnas Plasma Nutfah, 2003) dan Standard Evaluasi System for 
Rice (IRRI, 2013) meliputi panjang, lebar dan sudut tiga daun bagian atas serta luas daun $\left(\mathrm{cm}^{2}\right)$ metode Yoshida et al., (1976).

\section{HASIL DAN PEMBAHASAN}

Panjang dan lebar daun adalah faktor yang berhubungan dengan struktur kanopi tanaman. Bentuk kanopi yang dihasilkan akan berperan penting untuk menangkap radiasi matahari. Berdasarkan analisis deskriptif kultivar Bengkok memiliki karakter daun bendera yang lebih panjang sebesar $41,15 \mathrm{~cm}$. Karakter daun kedua dan ketiga terpanjang diperoleh pada kultivar Bontok sebesar masing-masing 72,90 dan $83,20 \mathrm{~cm}$, sedangkan karakter daun bendera, kedua dan ketiga terlebar diperoleh pada kultivar Rias Kuning sebesar masing-masing 2,43, 2,33 dan 2,28 cm (Tabel 1).

Panjang daun bendera kultivar padi gogo lokal tergolong dalam kriteria pendek kecuali kultivar Bengkok. Panjang daun kedua kultivar Rias Kuning, Simerah, Sebeso, Sigedul, Ramos Gunung dan Gembel tergolong dalam kriteria sedang, sedangkan kultivar Bontok, Rias Putih dan Bengkok tergolong dalam kriteria panjang. Panjang daun ketiga kultivar sebeso tergolong dalam kriteria sedang, kultivar Rias Kuning, Simerah, Sigedul, Ramos Gunung, Gembel, Rias Putih dan Bengkok tergolong dalam kriteria panjang, sedangkan Bontok tergolong dalam kriteria sangat panjang (Kriteria pendek 21-40 cm; sedang 41-60 cm; panjang 61-80 cm; dan sangat panjang $>80$ $\mathrm{cm})$.

Tabel 1. Rata-rata panjang daun $(\mathrm{cm})$, lebar daun $(\mathrm{cm})$ dan sudut daun $\left({ }^{0}\right)$ tiga daun bagian atas kultivar padi gogo lokal Aceh

\begin{tabular}{lccccccccc}
\hline & \multicolumn{3}{c}{ Panjang daun $(\mathrm{cm})$} & \multicolumn{3}{c}{ Lebar daun $(\mathrm{cm})$} & \multicolumn{3}{c}{ Sudut daun $\left({ }^{0}\right)$} \\
\cline { 2 - 9 } Nama kultivar & $\begin{array}{c}\text { Daun } \\
\text { bendera }\end{array}$ & $\begin{array}{c}\text { Daun } \\
\text { kedua }\end{array}$ & $\begin{array}{c}\text { Daun } \\
\text { ketiga }\end{array}$ & $\begin{array}{c}\text { Daun } \\
\text { bendera }\end{array}$ & $\begin{array}{c}\text { Daun } \\
\text { kedua }\end{array}$ & $\begin{array}{c}\text { Daun } \\
\text { ketiga }\end{array}$ & $\begin{array}{c}\text { Daun } \\
\text { bendera }\end{array}$ & $\begin{array}{c}\text { Daun } \\
\text { kedua }\end{array}$ & $\begin{array}{c}\text { Daun } \\
\text { ketiga }\end{array}$ \\
\hline Bontok & 39,45 & 72,90 & 83,20 & 2,25 & 2,25 & 2,05 & 6,00 & 10,00 & 15,00 \\
Rias Kuning & 33,80 & 57,35 & 74,35 & 2,43 & 2,33 & 2,28 & 5,50 & 10,50 & 17,50 \\
Simerah & 33,95 & 60,85 & 75,60 & 2,00 & 1,90 & 1,60 & 23,50 & 14,50 & 27,50 \\
Sebeso & 37,93 & 51,65 & 54,75 & 2,25 & 2,15 & 1,98 & 5,00 & 9,00 & 12,50 \\
Sigedul & 26,25 & 52,00 & 65,95 & 2,00 & 2,05 & 2,00 & 17,50 & 16,00 & 27,00 \\
Ramos Gunung & 29,73 & 59,30 & 72,75 & 1,98 & 2,00 & 1,95 & 19,50 & 10,50 & 25,50 \\
Gembel & 30,65 & 55,68 & 66,33 & 2,10 & 1,93 & 1,88 & 12,50 & 11,50 & 16,00 \\
Rias Putih & 29,83 & 61,83 & 75,03 & 2,32 & 2,32 & 2,13 & 11,75 & 10,00 & 19,75 \\
Bengkok & 41,15 & 64,78 & 70,20 & 2,05 & 1,83 & 1,78 & 87,00 & 29,25 & 48,25 \\
\hline
\end{tabular}

Sudut daun kultivar padi gogo lokal kecuali Bengkok berkisar antara 5,0-27,5 ${ }^{0}$, sehingga memiliki karakter kanopi daun yang tegak (kriteria tegak $<45^{0}$ ). Kultivar Bontok, Rias Kuning dan Sebeso memiliki sudut daun yang lebih kecil (5,0-17,5 ) (Gambar 1) dengan karakter daun termasuk berukuran besar sehingga lebih efisien dalam memanfaatkan radiasi matahari yang dapat meningkatkan fotosintesi dan hasil tanaman (Tabel 1). Bentuk kanopi yang ditentukan oleh tiga daun bagian atasmerupakan morfologi ideal yang berperan penting untuk menangkap lebih banyak energi cahaya, dan efisiensi penggunaan cahaya. Karakter kanopi daun yang tegak memungkinkan penetrasi dan distribusi cahaya yang lebih besar ke bagian bawah sehingga memiliki kanopi untuk fotosintesis yang lebih besar (Wahyuti et al., 2013).

Kultivar Bengkok memiliki sudut daun yang lebih besar berturut-turut 87,0, 29,2 dan $48,2^{0}$, dengan karakter daun bendera berposisi mendatar (kriteria mendatar 46-90 ${ }^{\circ}$ ), hal ini menyebabkan daun tidak efisien dalam memanfaatkan radiasi matahari, karakter kanopi daun yang mendatar atau terkulai dan terjadi perluasan daun akibat pola perkembangan menyebabkan daun bagian bawah akan ternaungi yang dapat mengurangi laju fotosintesis dalam kanopi (Tabel 1 dan Gambar 1). Lu et al. (2010)menyatakan bahwa pengaruh tipe tanaman terhadap hasil sangat tergantung pada struktur kanopi. Karakter morfologi tiga daun bagian atas yang ideal menurut Peng et al. (2008)daun bendera panjang $50 \mathrm{~cm}$, daun kedua dan ketiga panjang $55 \mathrm{~cm}$, sudut daun berturut-turut 5,10 , dan $20^{\circ}$, daun menyempit membentuk huruf $\mathrm{V}$, lebar $2 \mathrm{~cm}$, dan tebal. Berdasarkan hasil analisis kultivar padi lokal yang diamati walaupun memiliki karakter 
kanopi daun yang tegak (kriteria tegak $<45^{\circ}$ )belum tergolongdaun yang ideal untuk menjadi tanaman berdaya hasil tinggi.

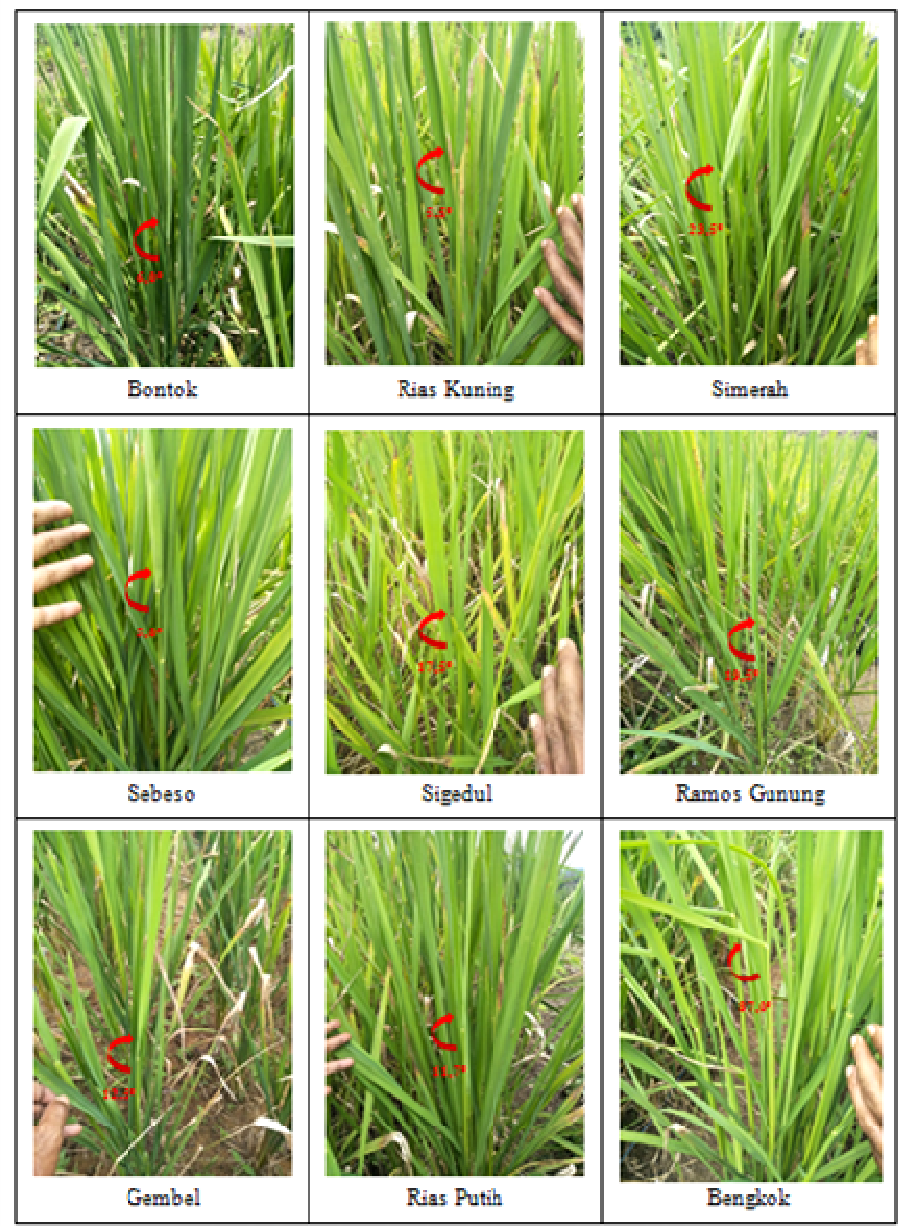

Gambar 1. Sudut daun bendera kultivar padi gogo lokal Aceh

Tabel 2. Rata-rata luas daun kultivar padi gogo lokal Aceh $\left(\mathrm{cm}^{2}\right)$

\begin{tabular}{lcc}
\hline \multirow{2}{*}{ Nama kultivar } & \multicolumn{2}{c}{ Luas daun $\left(\mathrm{cm}^{2}\right)$} \\
\cline { 2 - 3 } & Daun bendera & Daun kedua \\
\hline Bontok & 66,57 & 123,02 \\
Rias Kuning & 61,56 & 99,97 \\
Simerah & 50,93 & 86,71 \\
Sebeso & 64,00 & 83,29 \\
Sigedul & 39,38 & 79,95 \\
Ramos Gunung & 44,21 & 88,95 \\
Gembel & 48,23 & 80,13 \\
Rias Putih & 52,30 & 108,19 \\
Bengkok & 63,33 & 89,17 \\
\hline
\end{tabular}

Kultivar Bontok berdasarkan analisis deskriptif memiliki luas daun bendera dan kedua lebih besar masing-masing 66,57-123,02 $\mathrm{cm}^{2}$ (Tabel 2). Besarnya radiasi yang diintersepsi oleh tajuk tanaman sangat dipengaruhi oleh luas daun tanaman. Selama terjadi penyebaran intensitas cahaya matahari dalam kanopi juga terjadi absorbsi intensitas cahaya oleh tanaman. Fu et al., (2009)menyatakansudut daun berpengaruh terhadap distribusi luas daun danlengkungan daun mempengaruhi efektivitas dari luas daun. 
Tabel 3. Rata-rata nilai Ei (efisiensi intersepsi), Ea (efisiensi absorbsi) dan Epi (efisiensi penggunaan energi tertangkap) kultivar padi gogo lokal Aceh (\%)

\begin{tabular}{lcccc}
\hline \multicolumn{1}{c}{ Nama kultivar } & Umur & Ei (\%) & Ea (\%) & Epi (\%) \\
\hline Bontok & 10 MST & 92,72 & 95,99 & 6,28 \\
& 12 MST & 85,14 & 95,89 & 7,02 \\
\hline Rias Kuning & 10 MST & 93,50 & 95,25 & 5,56 \\
& 12 MST & 84,67 & 95,04 & 7,00 \\
\hline \multirow{2}{*}{ Simerah } & 10 MST & 75,57 & 96,10 & 6,67 \\
& 12 MST & 60,64 & 95,79 & 6,45 \\
\hline Sebeso & 10 MST & 92,95 & 96,58 & 6,83 \\
& 12 MST & 88,80 & 96,43 & 6,89 \\
\hline Sigedul & 10 MST & 79,24 & 96,46 & 6,39 \\
& 12 MST & 71,55 & 96,52 & 5,41 \\
\hline Ramos Gunung & 10 MST & 75,31 & 95,88 & 6,01 \\
& 12 MST & 57,50 & 96,29 & 6,19 \\
\hline Gembel & 10 MST & 81,42 & 96,69 & 4,17 \\
& 12 MST & 78,18 & 96,22 & 5,95 \\
\hline Rias Putih & 10 MST & 74,42 & 96,58 & 6,69 \\
& 12 MST & 45,29 & 96,35 & 8,71 \\
\hline Bengkok & 10 MST & 86,93 & 97,43 & 3,94 \\
& 12 MST & 86,11 & 95,59 & 5,81 \\
\hline
\end{tabular}

Pada Tabel 3 berdasarkan analisis deskriptif terlihat bahwa kultivar Bontok, Rias Kuning dan Sebeso memiliki efisiensi intersepsi (Ei) dan absorbsi (Ea) yang lebih tinggi, pada nilai efisiensi penggunaan energi tertangkap (Epi) terjadi peningkatan seiring bertambahnya umur tanaman. Kultivar Rias Putih memiliki nilai Ei lebih rendah namun memiliki nilai Epi yang tinggi dan terjadi peningkatan seiring dengan bertambahnya umur tanaman. Hal ini sesuai dengan karakter kanopi daun yang tegak dengan sudut daun yang lebih kecil (Tabel 2).

Efisiensi intersepsi (Ei) menunjukkan berapa persen radiasi matahari yang jatuh dapat ditangkap oleh tajuk tanaman sedangkan Nilai Epi menunjukkan berapa persen dari energi matahari yang telah tertangkap dapat diubah menjadi energi bahan kering tanaman. Daun tegak memungkinkan penetrasi dan distribusi cahaya lebih besar sampai ke bagian bawah dan merata, sehingga meningkatkan fotosintesis dan hasil tanaman. Fotosintesis tanaman pada kanopi daun tegak sekitar 20\% lebih tinggi dibanding kanopi daun terkulai pada kondisi ILD tinggi (Yoshida, 1981; Murchie et al., 2002).

Besarnya radiasi yang diintersepsi tanaman semakin meningkat seiring dengan bertambahnya umur tanaman dan kembali menurun menjelang panen. Radiasi matahari yang diintersepsi tanaman tergantung pada radiasi matahari yang datang yaitu yang sampai pada permukaan tajuk tanaman, indeks luas daun, kedudukan atau sudut daun dan distribusi daun dalam tajuk (Sitompul, 2016). Radiasi intersepsi sangat dipengaruhi oleh faktor luas daun dan kerapatan tanaman. Radiasi transmisi dipengaruhi oleh karakter kanopi yaitu luas daun, sudut daun, jumlah daun, dan ukuran daun (Djukri, 2005).

\section{KESIMPULAN}

Kultivar Bengkok memiliki karakter daun bendera yang lebih panjang sebesar $41,15 \mathrm{~cm}$. Karakter daun kedua dan ketiga terpanjang diperoleh pada kultivar Bontok sebesar masingmasing 72,90 dan 83,20 cm, sedangkan karakter daun bendera, kedua dan ketiga terlebar diperoleh pada kultivar Rias Kuning sebesar masing-masing 2,43, 2,33 dan 2,28 cm. Sudut daun kultivar padi gogo lokal kecuali Bengkok berkisar antara 5,0-27,50, sehingga memiliki karakter kanopi daun yang tegak (kriteria tegak $<45^{\circ}$ ). Kultivar Bontok, Rias Kuning dan Sebeso memiliki sudut daun yang lebih kecil $\left(5,0-17,5^{\circ}\right)$.

Kultivar Bontok, Rias Kuning dan Sebeso memiliki efisiensi intersepsi (Ei) dan absorbsi (Ea) yang lebih tinggi, pada nilai efisiensi penggunaan energi tertangkap (Epi) terjadi peningkatan seiring dengan bertambahnya umur tanaman. Hal ini sesuai dengan karakter kanopi daun yang tegak dengan sudut daun yang lebih kecil $\left(5,0-17,5^{\circ}\right)$ serta tergolong memiliki luas 
daun bendera dan kedua lebih besar berkisar antara 64,00-123,02 $\mathrm{cm}^{2}$ sehingga lebih efisien dalam memanfaatkan radiasi matahari.

\section{DAFTAR PUSTAKA}

Abdullah, B., Tjokrowidjojo, S. dan Sularjo. 2008. Perkembangan dan prospek perakitan padi tipe baru di Indonesia. J. Litbang Pertanian 27:1-9.

Djukri, 2005. Efek jarak tanam dan varietas terhadap distribusi cahaya dalam kanopi dan pertumbuhan (biomasa) kedelai. J. Pendidikan Matematika dan Sains.

Fu, J.D., B.W. Lee. 2009. Changes in photosynthetic characteristics during grain filling of a functional stay-green rice SNU-SG1 and its F1 hybrids. J. Crop Sci. Biotech. 11:75-82.

Ganghua, L., Xue, L., Wei, G., Yang, C., Wang, S., Ling, Q., Qin, X. and Ding, Y. 2009. Comparison of yield components and plant type characteristic of high-yield rice between Taoyuan, a 'special eco-site' and Nanjing, China. Field Crop. Res. 112:214221.

IRRI. 2013. Standard Evaluation System (SES) for Rice, 5th Edn. Manila, Philippines.

Komnas Plasma Nutfah. 2003. Panduan Sistem Karakterisasi dan Evaluasi Tanaman Padi. Departemen Pertanian.

Lu, C.G., Hu, N., Yao, K.M., Xia, S.J., Qi, Q.M. 2010. Plant type and its effects on canopy structure at heading stage in various ecological areas for a two-line hybrid rice combination, Liangyoupeijiu. Rice Sci. 17:235-242.

Monteith, J. and Unsworth, M. 2013. Principles of environmental physics: Plants, animals, and the atmosphere (4th ed.). Oxford, UK: Academic.

Murchie, E.H., Yang, J., Hubbart, S., Horton, P. and Peng, S. 2002. Are there association between grain-filling rate and photosynthesis in the flag leaves of field-grown rice. J. Exp. Bot. 53: 2217-2224.

Peng, S., G. S. Khush, P. Virk, Q. Tang, Y. Zou. 2008. Progress in ideotype breeding to increase rice yield potential. Field Crop. Res. 108:32-38.

Sitompul, M. 2016. Analisis Pertumbuhan Tanaman. Fakultas Pertanian Universitas Brawijaya. UB Press, Malang.

Slattery, R. A. and Ort, D. R. 2015. Photosynthetic energy conversion efficiency: Setting a baseline for gauging future improvements in important food and biofuel crops. Plant Physiology, 168(2), 383-392.

Sugito, Y. 2009. Ekologi tanaman. Pengaruh faktor lingkungan terhadap pertumbuhan tanaman dan beberapa aspeknya. UB Press, Malang.

Yoshida, S., Forno, D., Cock, J.H. and Gomez, K.A. 1976. Laboratory Manual for Physiological Studies of Rice. The International Rice Research Institute, Manila, Philippines.

Yoshida, S. 1981. Fundamentals of Rice Crop Science. International Rice Research Institut, Manila, Philippines.

Zhu, X.G., Long, S.P. and Ort, D.R. 2008. What is the maximum efficiency with which photosynthesis can convert solar energy into biomass. Current Opinion in Biotehnology, 19(2), 153-159. 